c. a-naphthyl carbamate of Fract. VI. M. P. $61^{\circ}$ (isoamylalc.68 ${ }^{\circ}$ )

(7) Optical rotation of mixture : Subst. Mixture of fract. III VIII.

$[\alpha]^{26.5 \circ}=-2.57^{\circ} \quad r=-2.222^{\circ} \quad l=2.2 \mathrm{dm} \quad \mathrm{C}=39.21 \%$ (alcohol solution)

(8) Valine recovered from the reșidue: $77 . \mathrm{g}$.

(9) Succinic acid (M. P. $187^{\circ}$ ) obtained: $30.36 \mathrm{~g}$.

The acid may perhaps be formed from sugar alone.

BIBLIOGRAPHY

(1) M. Yamada: Bull. Agricult. Chem. Soc. 8, 97 100 (1932).

\title{
On the Alcoholic Fermentation of Amino-acids.
}

Part VIII. Decomposition of glutaminic acid

and asparagine by saké yeast.

By Masakazu Yamada

(Received October 29, 1934)

In the series of the auther's previous experiments, the mother substance of normal propyl alcohol as an ordinary constituent of fusel oil has not yet been found. On the one hand, n-propyl alcohol shows quite faint color reaction with vanilline- $\mathrm{H}_{2} \mathrm{SO}_{4}$ reagent and so the previous preliminary experiment with glutaminic acid or asparagine ought to be examined again. In those cases no remarkable production of fusel oil were perceived ${ }^{(1)}$. F. Ehrlich supposed first that glutaminic acid was the mother substance of $n$-propyl alcohol, but he obtained succinic acid instead of the alcohol contrary to his expectation.

The auther's experiment showed that glutaminic acid or asparagine was not the mother substance of $n$-propyl alcohol and gave very poor yield of fusel oil as the preliminary experiment had shown. The superior production of succinic acid was observed in the case of glutaminic acid.

\section{EXPERIMENTAL}

I. Decomposition of glutaminic acid by saké yeast.'

(1) Glutaminic acid: Ajino-moto (sodium-glutaminate) was used.

(2) Medium : Modified Hayduck solution with $0.5 \%$ of Na-glutaminate in place of asparagine.

(3) Fermentation: The details of experiments are the same as the case of leucine. $30 \mathrm{~L}$ of the fermentation liquid was distilled. 
(4) Products :

alcohol $4.3 \%$, fusel oil $0.025 \%$, total acid $0.1534 \%$

yield of alcohol

1451 cc (ca $95 \%)$

" $"$ oil (B. P. above $100^{\circ}$ ) $1.8 \mathrm{~g}$

" $"$ yeast

$88 \mathrm{~g}$

(5) Fractionation of the oil.

\begin{tabular}{c|c|c||c|c|c}
\hline \hline Fract. & B. P. & Yield (g) & Fract. & B. P. & Yield (g) \\
\hline I & $95 \sim 120^{\circ}$ & 0.3 & III & above 128 & total \\
II & $120 \sim 128^{\circ}$ & 0.7 & & 0.7 \\
\hline
\end{tabular}

The main part distills in amyl alcohol fraction but perhaps may not be derived from glutaminic acid.

(6) Succinic acid obtained from the residue: $24 \mathrm{~g} \mathrm{M.P.} 184^{\circ}$.

II. Decomposition of asparagine by saké yeast.

(1) Asparagine: prepared by Merck.

(2) Medium : Hayduck solution.

(3) $30 \mathrm{~L}$ of the fermentation liquid was distilled at 10 days after inoculation of saké yeast.

(4) Products :

$$
\begin{array}{ll}
\text { alcohol : } 5 \% \text {, fusel oil } 0.03 \%, & \text { total acid } 0.0851 \% \\
\text { yield of alcohol } & 1354 \text { çc (ca 93\%) } \\
\text { " " oil (B. P. above } 100^{\circ} \text { ) } & 0.4 \mathrm{~g} \\
\text { " " yeast } & 84.5 \mathrm{~g}
\end{array}
$$

(5) From the residue $0.2 \mathrm{~g}$ of acetic acid as volatile acid and $4.0 \mathrm{~g}$ of succinic acid (M. P. $183^{\circ}$ ) were obtained. When crystals of succinic acid were treated with cinchonine, minute quantity of cinchonine-malate was crystallized out. After recrystallization from acetone, it melts at $197 \sim 8^{\circ}$. (Cinchonine malate).

\section{BIBLIOGRAPHY}

(1) M. Yamada: Bull. Agricult. Chem. Soc. 8, 95 97 (1932).

\begin{tabular}{|c|c|c|c|c|c|c|}
\hline \multirow{2}{*}{ Substrate } & \multirow{2}{*}{$\begin{array}{l}\text { high alcphol } \\
\text { produced }\end{array}$} & \multicolumn{3}{|c|}{ M. P. of derivatives } & \multicolumn{2}{|c|}{ yield $(\mathrm{g})$} \\
\hline & & $\begin{array}{l}\text { 3.5-dinitro } \\
\text { benz. }\end{array}$ & $\begin{array}{c}\text { phenyl car- } \\
\text { bamate. }\end{array}$ & $\begin{array}{l}a \text {-naphthyl } \\
\text { carbamate. }\end{array}$ & $\begin{array}{l}\text { succinic acid } \\
\text { (total liquid) }\end{array}$ & Yie' () \\
\hline glycocoll & amylalc. & $58 \sim 63^{\circ}$ & $46 \sim 5.0^{\circ}$ & $59^{\circ}$ & $11 \mathrm{~g}(32.2 \mathrm{~L})$ & $88.5 \mathrm{~g}$ \\
\hline$d$-alanine & isobutylalc. & $83 \sim 4$ & 80 & 一 & $-(30 \mathrm{~L})$ & - \\
\hline$d-l$-alanine & isobutylalc. & 86 & 83 & - & $1.5(37.5 \mathrm{~L})$ & 82.4 \\
\hline
\end{tabular}

On the Alcoholic Fermentation of Amino-acids.

By Masakazu YAMADA

Summerized results are as follows 
[Vol. 11

\begin{tabular}{|c|c|c|c|c|c|c|}
\hline $\begin{array}{c}d-l-a \text { amino- } n \\
\text { butyric acid }\end{array}$ & act. amylalc. & 81.5 & 32.5 & 79 & $0.6(13.2 \mathrm{~L})^{\prime}$ & - \\
\hline$d-l-n$-valine & $n$-butylalc. & 70.5 & 57 & 70 & $3.5(30)$ & 49 \\
\hline$d-l$. valine & $\begin{array}{l}\text { amylalc. B. } \\
\text { P. }\left(123 \sim 30^{\circ}\right)\end{array}$ & 65 & $40 \sim 43$ & 59 & $30.36(30)$ & $40^{*}$ \\
\hline$d-l$. leucine & isoamylalc. & 63 & 57.5 & - & $2.0(23)$ & 38 \\
\hline asparagine & & - & - & - & $4.0(30)$ & 84.5 \\
\hline$\underset{\text { acid }}{\operatorname{glutaminic}}$ & amylalc. & - & - & - & $24(30)$ & 88 \\
\hline control & $\begin{array}{c}\text { trace of amyl } \\
\text { alc. }\end{array}$ & & & & $3.0(20)$ & $54^{*}$ \\
\hline
\end{tabular}

* together with added yeast.

\title{
On the Glycerin Fraction in saké.
}

\author{
By Masakazu YAMADA \\ (Received October 29, 1934)
}

(1) The glycerin fraction of sake $(10 \mathrm{~L})$ and moto-mash $(50 \mathrm{~L})$ were isolated by ordinary alcohol-ether extraction method from the extracts and $0.384 \%$ in saké and $0.754 \%$ in moto-mash were found. The fraction consists of $2 \cdot 3$-butylenglycol (B. P. $177 \sim 185^{\circ}$ ) and glycerin (B. P. $156 \sim 169^{\circ} / 7 \mathrm{~mm}$ ). The ratio of two compounds are $1: 20$ in saké and 1:10 in moto mash.

(2) Diphenyl-carbamate of $2 \cdot 3$-butylenglycol prepared melts at $201^{\circ}$ and contains nitrogen $8.61 \%\left(8.54 \%\right.$ calculated for $\left.\mathrm{C}_{18} \mathrm{H}_{20} \mathrm{~N}_{2} \mathrm{O}_{4}\right)$.

(3) Specific rotatory power of butylenglycol :

$$
[\alpha]_{D}^{320}=+9.70
$$

(4) Both constituents are necessary for the refined seweet taste of saké.

\section{On the Variation of Sugar-content in saké.}

\author{
By Masakazu YAMADA \\ Katsuichirō TAKAGISHI \\ (Governmental Institute of Brewing, Takinogawa, Tokyo.)
}

(Received October 29, 1934)

The sweet taste of saké is mainly due to sugar in it, while we found that sugar content was not constant but increased day by day with average speed of $0.0284 \%$ a day until pasteurization after the stage of compression of ' moromi.**

* Moromi $=$ saké lees. 